\title{
МИСТЕЦТВОЗНАВСТВО
}

\author{
DOI: https://doi.org/10.32839/2304-5809/2021-5-93-7 \\ УДК 741.5:821.161.2-341]-048.445
}

Баран Н.В., Гнаткович О.Д.

Львівський національний університет імені Івана Франка

\section{КЛАСИФІКАЦІЯ ТА СПЕЦИФІКА СУЧАСНИХ УКРАЇНСЬКИХ КОМІКСІВ}

\begin{abstract}
Анотація. В наш час індустрія графічних романів та коміксів є невід'ємною частиною сучасного простору масової культури, а кількість грунтовних досліджень даної продукції є вичерпною. Більшість дослідників індустрії графічних творів розглядають хронологію вітчизняних коміксів у контексті історії закордонних продуктів, уникаючи їхнього детального розгляду та встановлення класифікації. У цій статті розглянуто специфіку українських коміксів, з'ясовані причини їх фрормування, спираючись на тенденцію створення графічних творів іноземних країн. Простежено жанрову різнотипність і різноманітність характерів коміксів України та розглянуто явище Революції Гідності як зміну вектору розвитку індустрії коміксів. Також стаття містить спробу встановлення уніфікованого класифрікування вітчизняної графрічної продукції та хронологічного порядку їх випуску.
\end{abstract}

Ключові слова: комікс, графічний роман, графічна література, історичні комікси, поп-культура.

Baran Nazariy, Hnatkovych Oksana Ivan Franko National University of Lviv

\section{CLASSIFICATION AND SPECIFICITY OF MODERN UKRAINIAN COMICS}

Summary. Swiss writer Rudolf Tepfer introduced the first name "comics" in the first half of the XIX century. With this word, he described his works in the form of a series of drawings with textual accompaniment. The term "comic" describes two types of graphics that are different in purpose and function. A modern understanding of comics, which Americans call a "comic book," is published in the form of a magazine or small book. This type tells the story through visual images. When the second type, a comic strip, is a small picture in the form of a small number of panels, which is concise in the coverage of the plot. Still, it contains a specific semantic load and, by its nature, resembles a political caricature. In its dualistic character, the history of Ukrainian comics does not have a fixed date of the appearance of the first works. Researchers in this branch of literature begins the history of domestic comics in different ways. Since we are interested in the "comic book" type, it would be a mistake to assume that Ukrainian comics appeared in the 1930s in the Soviet Ukraine magazine "Red Pepper", published in Kharkiv, in which the works were comic strips. The appearance of the first Ukrainian comic book, such as the comic book, dates to 1991 when Yuri Logvin's comic book "Prince Oleg's March on Constantinople" was published. The comics productions increase after the Revolution of Dignity $2013-2014$. This phenomenon manifested in the number of new publications and new publishers. However, Ukrainian comics do not characterize by genre unanimity. Considering the stylistic specifics of most graphic works of domestic production, not translations, all comics, by type, can be divided into three groups: those that follow the trends of world popular culture; those that graphically interpret Ukrainian literary works; and those that describe or interpret periods or moments in Ukrainian history. The last group is divided into two subcategories with different functions. One is marked by a plot narrative of historical events with a set of dry facts, and its position seems purely informational and educational. Another subcategory of comics is a mixture of historicity and lower category genres. The historical past of this subcategory acts as the basis of the work.

Keywords: comics, graphic novel, graphic literature, historical comics, pop culture.

$\Pi^{2}$ остановка проблеми. Сьогодні комікси є міцною складовою масової популярної культури, під впливом якої виросло не одне покоління. В Україні дана індустрія знаходиться лише на початковому рівні зародження, проте, чималими зусиллями, вона намагається наслідувати чи, навіть, перегнати закордонний продукт.

Комікс є засобом масової комунікації, оскільки його споживачами є велика аудиторія. Текстовий супровід та візуальна складова твору грають знакову роль у формуванні вербально-іконічної фрункції та фрормування комунікативного процесу. Також можна простежити перевагу коміксу над виключно текстовими продуктами - вона полягає у простоті сприйняття читачем інформації завдяки зору [23]. Комікс із видимим поєднанням іконічних та вербальних знаків забезпечуе своїй аудиторії легке сприйняття у вигляді повторюва- ності сюжетів і характеризації персонажів. Такі твори, що на думку У. Еко є привабливими психологічною розрядкою, відчуттям розваги та відпочинку, характерні також освітньою фрункцією, яка безпосередньо залежить від вмісту наукової, історичної чи політичної інформації [23].

Попри велику популярність та широке захоплення ринку комікс, як елемент масової комунікації, потребує великого дослідження та класифікації стилістичної та ідейної складових творів. Як згадуе Н. Космацька, культура коміксів не прижилася в Україні [7], а Б. Філоненко стверджує, що українського коміксу, в сучасному розумінні, не існуе, а є лиш тільки спроби створити його [20]. Тож, якщо українська індустрія коміксів лиш на початку свого шляху, то можна провести паралель із цією ж індустрією США у 1930-40 рр. Проdpecop Девід Оніон згадуе перші американські 
комікси, як інструмент пропаганди: популярний Супермен 3 іншої планети виступає емігрантом, чим задовольняє характеристику американської нащї, під час Великої депресії у коміксах Бетмен бореться проти світу корумпованих бізнесменів, тим самим допомагаючи бідним людям, Капітан Америка виступає символом патріотизму країни та вносить чималий вклад у зображення Америки у другій світовій війні [25]. У 1977 році автор коміксів Майкл Услан заявив: «3 1930-х років до сьогоднішнього дня комікси висловлювали тенденції, звичаї та проблеми американського життя. Комікси - це вітрина національних поглядів, сленгу, моралі, звичаїв, традищій, расових настроїв, примх, героїв дня і всього, що складає наш спосіб життя» [25]. Дана цитата підтверджує важливість дослідження смислового та стильового навантаження коміксів та їхне віддзеркалення iз загальнонаціональними тенденціями їх місця народження.

Аналіз останніх досліджень та публікацій. Українськими дослідниками специфріки та фрункціональності коміксів є Н. Космацька [7], А. Онкович [14], Б. Філоненко [20] та Т. Троян [19]. Значимими працями для дослідження даного типу графічного твору, здебільшого, є праці іноземних авторів, як-от У. Еко [22], А. Волков, К. Кутузов [3], Дж. Томпсон [26]. У науковому просторі України, на жаль, відсутні великі монографрії чи наукові дослідження стосовно явища українського коміксу. Цінний розгляд популяризації та перспективи індустрії коміксів в Україні містить стаття аспіранта Київського національного університету культури і мистецтв Дмитра Белова [2]. Автор описує появу та розвиток коміксу як продукту інформаційної культури у світовому контексті, згодом стисло розглядаючи зародження і розвиток даної індустрії на теренах України. Проте Д. Бєлов не доторкається до проблеми класифрікації та ідеології тих чи інших коміксів, про що йтиметься у даній статті.

Виділення не вирішених раніше частин загальної проблеми. Більшість дослідників проблем коміксів різного характеру, здебільшого, розглядають питання хронології українського коміксу, помилково називаючи комікси навіть газетні графічні елементи, середовище його існування чи явище вітчизняного графічного твору в контексті історії світової сфери коміксів. В українському науковому середовищі простежуеться явний брак досліджень власне вітчизняних творів, його класифікації та розгляду стилістики.

Мета статті. Головною метою ціё̈ роботи e встановлення хронології українського коміксу у його сучасному розумінні та спроба класифікації вітчизняної графрічної продукції за смисловим та ідейним значенням.

Реалізація мети супроводжуеться поставленим цілям:

- розглянути проблему термінології коміксу;

- дослідити ідейне натхнення українських графічних творів;

- визначити інтенсивність публікації вітчизняних коміксів;

- класифікувати українські комікси за стилістичною та ідейною ознаками.

Виклад основного матеріалу. Комікс - реальна чи вигадана розповідь у стилі послідовного викладення малюнків із короткими текстами [14]. У різних країнах цей вид літератури може нести окрему назву: так у Франції комікси, як окремий вид літератури, називають «les bandes dessinées» (не плутати 3 «le bande dessinée», яка $є$ концепцією чи технікою, що реалізуе мистецтво коміксів [24]), у Японії - манга, Китай - маньхуа тощо [26].

У даній статті термінологія відіграє не останню роль при класифікації вітчизняних і не тільки продуктів сфери індустрії коміксів, тому варто пам'ятати наступне.

Першим назву «комікс» швейцарський письменник Рудольф Тепфер ввів у першій половині XIX ст. Цим словом він охарактеризував свої роботи у вигляді серії малюнків із текстуальним супроводом [2]. Однак, поняття «комікс» для творів XIX ст. і сьогодення характеризує кардинально різні види творів. Цим терміном можна охарактеризувати два, відмінні за призначенням та функцією, типи графічних творів: це сучасне розуміння коміксу, який американці називають "comic book», у вигляді журналу чи невеликої книги, в якому розповідь відбувається 3 допомогою візуальних зображень; а також газетні стрипи («соmic strip») - невелика в об’емі картинка у вигляді невеликої кількості панелей, яка є стислою у висвітленні сюжету, однак містить певне смислове навантаження та, за своїм характером, нагадуе політичну карикатуру [3]. Тому називати обидва види творів единим терміном «комікс», вважаючи їх однаковими за смисловим значенням, буде помилковим.

У культурному середовищі США найбільш популярною $є$ тенденція супергероїки, що почалася із так званого «Золотого періоду» коміксів 1938-1950 pp. Даний шаблон зародився із дебюту Супермена в творах та продовжилася появою йому подібних персонажів-надлюдей аж по сьогодні [3]. В Європі явище масового поширення коміксів (bande dessinee або BD) завдячуе діяльності франко-бельгійської школи, твори яких, на відміну від американських, призначених для підліткового віку, відрізняються акцентом на дорослу аудиторію, та, відповідно, на теми із серйозним підтекстом, чи то проблема міграції, голокосту, чи то політики [6].

Окрім продуктів для молодої аудиторії, на кшталт американських коміксів, в Україні, здебільшого, ця індустрія, наслідуючи франко-бельгійські комікси, використовуе історичну базу за основу сюжетів своїх найвідоміших творів, як-от серії коміксів "Мамай» (2008 р.), «Максим Оса» (2008 р.), «Даогопак» (2012-2016 рр.), «Кіборги» (3 2018 р.), «Воля» (з 2017 р.), «Герой поневолі» (2014-2017 рр.) тощо. Графрічні романи можуть описувати події, що розгортаються навколо певного козака, який блукає по землях Війська Запорозького, демонструвати сюжети протистояння «кіборгів» та російських військ на Сході України, чи навіть містити поєднання ключових осіб і подій Української революції 1917-1921 рр. 3 елементами френтезі, франтастики чи хорору. Тому, українські комікси, в основі яких лежить історична оповідь, формують історичну пам'ять, що за твердженням багатьох науковців, у тому числі О. Готри, є важливим чинником у процесі творення національної ідентичності [5, с. 143-155], враховуючи і те, що історичні ре- 
алії у творах переплітаються із художньою творчістю авторів, то не виключаймо той фракт, що комікси можуть містити "зловживання пам'яттю", яка потенційно спроможна інтерпретувати інформацію як інструмент певної ідеології [12].

Також на світанку своєї історії західні комікси, в їх сучасному розумінні, не виникли без причин. Кожна нація, повинна мати свої героїчні символи, які несуть патріотичну єдність і стали би маркером окремої нащії. Так, культура США до 1938 р., коли вийшов перший випуск про Супермена, не містила власних літературних героїв, які були би аналогічними богам чи персонажам міфрологій народів Свропи. Тільки з початком Другої світової війни, комікси повняться безліччю символічних елементів, через які вбачалися ті чи інші картини, призначені для росту патріотичного духу та створення символів країни [3, с. 13]. Появі європейських коміксів притаманна мета розвитку світогляду читачів шляхом їх ознайомлення з історичними, культурними, політичними та сощіальними аспектами реальності [21]. Тому, на фроні попереднього, перед нами чітко постають питання появи власне українських коміксів, в тому числі історичних, та з яких причин індустрія коміксів України набула інтенсивного продукування творів у другому десятилітті цього століття.

У своєму дуалістичному типажі історія українських коміксів не має усталеної дати появи перших творів. Дослідники цієї гілки літератури починають історію вітчизняних коміксів порізному. Оскільки нас цікавить тип «comic book», то буде помилково вважати твердження члена перекладацької спільноти «Студія Ворон» та дослідника коміксів Дениса Скорбатюка, про те, що українські комікси з'являються у 30-х роках ХХ століття у журналі Радянської України «Червоний перець», що видавався у Харкові, в якому твори являли собою стрипи [13].

Також прикладами українських стрипів насичені періоди Першої світової війни та міжвоєнний період [18]. У першому випадку, протягом військових дій, виникає попит на лубок, тобто стрипи, що видавалися у вигляді плакатів, та які, за твердженням Олександра Маєвського, є дійовим інструментом пропаганди і регулюеться політичними подіями [9, с. 14]. Таку ж фрункцію стрипи мали і в період Другої світової війни.

У міжвоєнний період стрипи надалі друкувалися в журналах. На Західній Україні видавався журнал «Комар», характерний сатиричними зображеннями, який проіснував до 1939-го року [13]. У радянській Україні, «соміс strips» з'являлися в газетах та журналах («Український перець», «Перець», «Перченя», «Веселка» тощо), аж до здобуття незалежності Україною.

Поява першого українського коміксу на кшталт «comic book», припадає на 1991 р. коли був виданий комікс Юрія Логвина «Похід князя Олега на Царгород» [8]. Цей твір видавався частинами у журналі «Соняшник» протягом січня-червня 1991 р. Цілісні «comic book» в Україні виходять 3 друку, починаючи 3 наступного року i, здебільшого, автором постає Сергій Позняк. Першими графрічні новели, розповіді про часи Давньої Русі від С. Позняка «Облога Києва печенігами» [17] та "Бій богатирів" [15]. Окрім низки історичних коміксів 90-років, що зображали різні періоди історії України (тематика Русі: «Перші київські князі»; козацтва: «Буйвітер», «Марко Пиріг, запорожець), існували комікси різних жанрів, як-от, «Комікс-збірка» [16] з жанрами детективу, франтастики та хорору, видана у Львові в 1993 р., чи графрічний твір Позняка побудований на основі «Фатальних яець» Михайла Булгакова [18].

Історичні комікси видаються й по сьогодні, однак, якщо слідкувати за періодичністю випусків одноманітних творів, в основі яких лежать історичні події, то найінтенсивнішим $є$ період перших років незалежності України. Якщо розглядати статистику продукції коміксів станом на 2018 рік, складену засновником видавництва коміксів «Vovkulaka» Ярославом Мішеновим [11] (діаграма 1), то наочно бачимо, що вміст пригодницько-історичних творів становить 4\% усіх виданих коміксів того ж року, а тенденція виробництва зазнала зменшення у вигляді -67\% до 2017 р. (діаграма 2). Однак, судячи 3 наявності у статистиці пунктів «франтастика-френтезі» та «графрічний роман», можна припустити, що Я. Мішенов включив у названі 4\% однотипні історичні комікси, як-от вищезгадані «Облога Киева печенігами» чи «Бій богатирів». На жаль, на сьогодні не існуе уніфікованого окреслення рамок історичного коміксу та систематизованого викладу критеріїв, за яким його можна характеризувати. Так, два томи коміксу «Воля» за жанром $\epsilon$ альтернативною історією, стімпанком, дизельпанком, франтастикою та фентезі, проте глибокою основою твору є реальні персони та події Української революції 1917-1921 рр. [4], а автори графрічного роману «Герой поневолі» так і називають свій твір «історичним коміксом». Тому, виходячи 3 викладених фрактів, можна зробити висновок того, що протягом років історичні комікси перетекли з одноманітного типу до суміші жанрового різноманіття, проте в обох випадках історичні реалії надалі несуть ключову роль.

Збільшення випуску творів можна побачити після Революції Гідності 2013-2014 рр., а саме це проявилося у кількості видань та видавництв. Про вплив Свромайдану та відмову від продуктів російських видань на користь вітчизняних твердять Денис Скорбатюк [13] та Богдан Кордоба [10], львівський письменник і видавець. Тенденція українізації коміксової продукції притаманна і у перекладницькій сорері. Так видавництва «Рідна мова", "Ірбіс Комікси», "Fireclaw», "Мольфар Комікс» та згодом інші, починаючи з 2017 р. видають українською мовою світові графрічні твори від таких компаній, як "DC Comics», «Marvel Comics», «Vertigo», «Blizzard Entertainment» тощо.

Притаманність українським коміксам жанрової одностайності - відсутня. Розглядаючи стильову специфіку більшості графічних творів вітчизняного виробництва, не перекладів, усі комікси, за типажем, можна поділити на три групи. У число першої входять графрічні твори, характерні жанрами із категорії нижчого порядку [1], тобто детектив («Хроніки Аптауна»), наукова франтастика («Майкл 1), френтезі («Троє проти зла»), екшн та супергероїка («Укрмен»), військова драма («Кіборги»), горор («Жах»), дитячий («Княжа Воля. Легенди Хом’якиева») тощо.

В другій категорії присутні твори класичної української літератури адаптованих на графіч- 


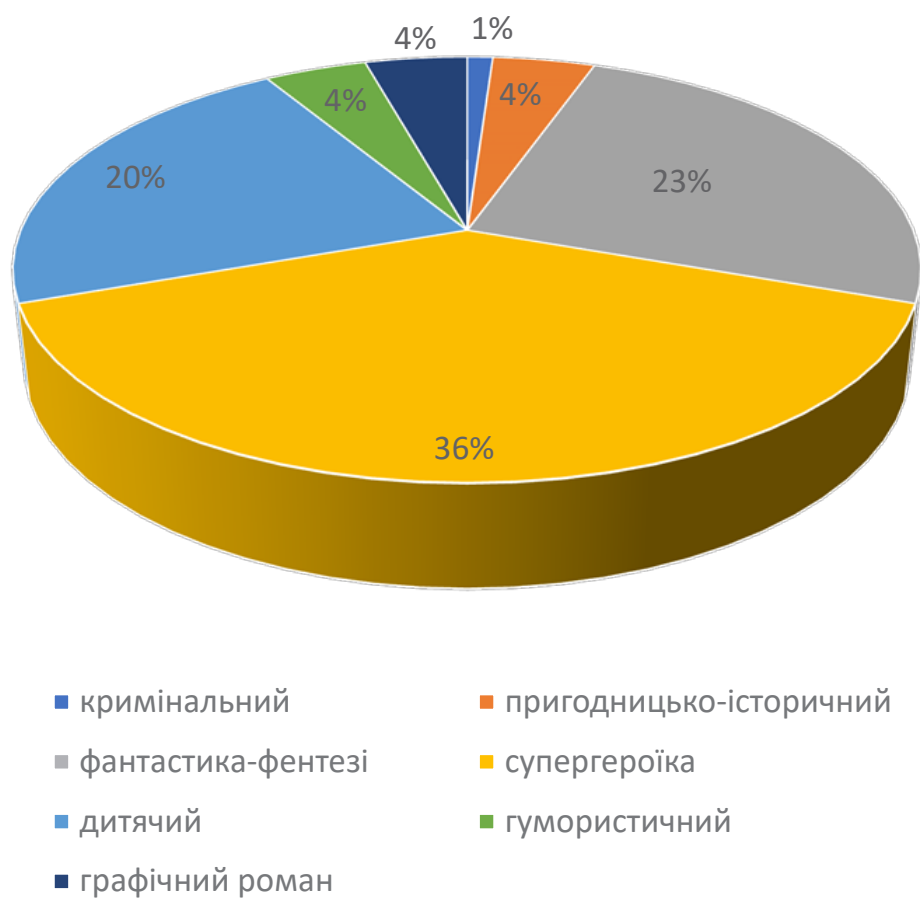

Діаграма 1. Відсоткова кількість пожанрового видання коміксів 2018 р.

Джерело: розроблено автором за даними [11]

ний лад. Початок такої тенденщії прослідковуеться з 1993 р., коли видавництво «Генеза» випустило 3 друку комікс «Страшна помста» за мотивами однойменної повісті Миколи Гоголя, а згодом «Вій», «Ніч перед Різдвом», «Тарас Бульба». Вже у 2000-х адаптацією класичної літератури займаеться не одне видавництво: «Грані-Т», «Книга», «Фрески» видають комікси на основі творів Івана Франка, Миколи Куліша, Григорія
Квітки-Основ'яненка, Тараса Шевченка, Івана Котляревського та ін.

До останньої групи відноситься стиль, який заклав початок українського коміксу, як такого. Саме з щієї причини, на нашу думку, історичні комікси заслуговують окремої категорії. Саму групу можна розділити дві підкатегорії, характерні різним функціям. Перша відзначаеться сюжетом-розповіддю історичних подій з набором су-

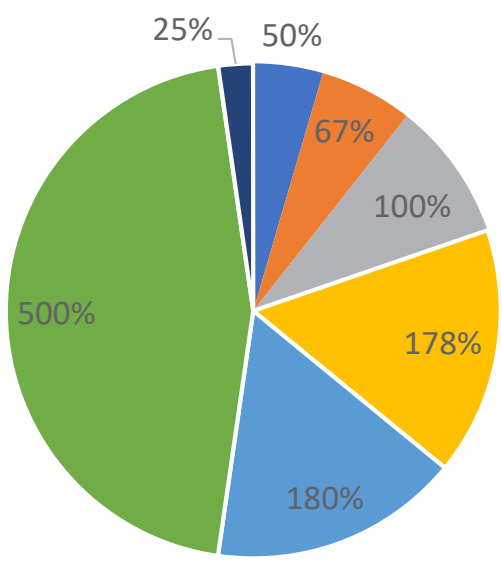

- кримінальний

- фантастика-фентезі

- дитячий

- графічний роман
" пригодницько-історичний

ш супергероїка

- гумористичний

Діаграма 2. Відсоткове зменшення пожанрових випусків до 2017 p. 
хих фрактів, а їі фрункцію можна описати скоріше як суто інформаційно-пізнавальну та освітню. Наприклад, такі комікси цієї групи, як «Облога Киева печенігами», «Бій богатирів» чи «Володимир князь Київський», характерні викладенням сюжету від лиця вигаданого чи реального героя, однак сам світ та події не виходять за рамки історичної площини, можливого та реального. Отже, цей вид творів виступає, як адаптація історичних реалій через графічно-літературну призму.

Історичні комікси другої підкатегорії демонструються як суміш історичності та жанрів категорій нижчого порядку, де історичне минуле виступає базисом твору. Тобто ці твори виступають поєднанням типів попередньої підкатегорії та першої категорії з жанрової різноманітністю. Так, комікси на козацьку тематику «Максим Оса» та «Даогопак» у стильовому характері виступають детективом та френтезі, відповідно, а події томів «Воля» - франтастикою та стімпанком на основі подій і персонажів Української революції 19171921 pp. Такі графічні твори, будучи вільними у художньому творенні, легко даються для ана- лізу історичної достовірності та пошуків смислового підтексту, адже сюжет та світ розвиваються виключно через призму уявлення та ідей авторів.

Висновки. Відштовхуючись від термінології графрічних творів, їхньої стилістичного та ідейного характерів, цілком реально стверджувати, що широку класифікащію українських коміксів варто здійснювати, спираючись не на жанрову притаманність, а на ідейну та стильову специфіку. Таким чином, вітчизняна продукція коміксів за попередніми критеріями форомуе три групи: такі, що наслідують тенденції світової популярної культури; такі, що графічно інтерпретують українські літературні твори; та такі, що описують або інтерпретують періоди чи моменти української історії.

Варто також підкреслити, що при встановленні на законодавчому рівні в Україні чіткого проєвропейського вектору розвитку, індустрія коміксів в країні значно зросла. Так політична ситуація зумовила збільшення перекладів іноземної графрічної продукції на українську мову та спровокувала утворенню нових власне вітчизняних творів.

\section{Список літератури:}

1. Абрамчук О.В. Жанри сучасної української літератури. Матеріали XLV Науково-технічної конфберениї ВНТУ, Вінниця, 23-24 березня 2016 p. URL: http://conferences.vntu.edu.ua/index.php/all-hum/all-hum-2016/ paper/view/108 (дата звернення: 20.05.2021).

2. Белов Д. Комікс як продукт інформаційної культури. Наукові праці національної бібліотеки Украӥни iм. B.I. Вернадського. 2018. Вип. 49. 49. С. 71-88. URL: http://nbuviap.gov.ua/images/naukprazi/49.pdf (дата звернення: 20.05.2021).

3. Волков А. Кутузов В. Тайная история комиксов. Москва : АСТ, 2017. 336 с.

4. Воля / В. Бугайов, Д. Фадеєв, О. Бондаренко, О. Филипович. Дніпро : Asgardian Comics, 2017.56 c. (Toм 1).

5. Готра О. Історична пам'ять як чинник формування ідентичності. INTERMARUM: історія, політика, культура. 2015. № 2. С. 143-155.

6. Захарова И.В. Комиксы (La bande dessinée) во фрранко-бельгийской культуре - Московский государственный университет имени М.В. Ломоносова. 2017. URL: http://vernsky.ru/pubs/6836/Komiksy_La_bande_dessin_e_ vo_franko-belgiyskoy_kulture (дата звернення: 20.05.2021).

7. Космацька Н.В. Мова сучасного коміксу як явища масової культури. Мова і культура. 2012. Вип. 15. Т. 4. C. 15-20. URL: http://nbuv.gov.ua/UJRN/Mik_2012_15_4_5 (дата звернення: 20.05.2021).

8. Логвин Ю. Похід князя Олега на Царгород. Соняшник. 1991. URL: http://chtyvo.org.ua/authors/Lohvyn/ Pohid_kniazia_Ihora_na_Tsarhorod/ (дата звернення: 20.05.2021).

9. Маєвський О. Формування візуальних образів напередодні та у роки Першої світової війни. Краєзнавство. 2018. № 4. C. 14 .

10. Мартинович Ю. Комікс - це майже фільм: Як в Україні відновлюють забутий дев'ятий вид мистецтва - ZIK. URL: https://zik.ua/news/2019/01/07/komiks_tse_mayzhe_film_yak_v_ukraini_vidnovlyuyut_ zabutyy_devyatyy_vyd_1481711 (дата звернення: 13.05.2019).

11. Мішенов Я. Комікси в Україні: результати 2018 року - Vertigo. URL: https://vertigo.com.ua/comics-inukraine-2018/ (дата звернення: 20.05.2021).

12. Нагорна Л.П. Історична пам'ять: теорії, дискурси, рефлексії. Інститут політичних і етнонаціональних досліджень ім. І.Ф. Кураса НАН України, 2012. 328 с.

13. Назарова Є. «Укрмен» та інші супергерої. Як розвивається українська індустрія коміксів - Радіо Свобода. URL: https://www.radiosvoboda.org/a/yak-rozvyvayetsya-ukrayinska-industriya-komiksiv/29641200.html (дата звернення: 20.05.2021).

14. Онкович А.В. Комиксы как форма визуальной медиакомуникации - Институт высшего образования Национальной академии педагогических наук Украины. 2017. URL: https://dspace.kpfu.ru/xmlui/bitstream/handle/ net/30146/viscom2014-85-92.pdf (дата звернення: 20.05.2021).

15. Позняк С. Бій богатирів. Львів : Хортиця, 1992.

16. Позняк С., Дергачов О., Коваленко О. Комікс-збірка № 1. Львів : Фенікс Лтд, 1993. 20 с.

17. Позняк С. Облога Києва печенігами. Київ : «Україна», 1992.

18. Ринк О. Таемна історія українських коміксів - Vertigo. URL: https://vertigo.com.ua/history-of-ukrainiancomics/ (дата звернення: 20.05.2021).

19. Троян Т. Г. Формування комікс-культури: переваги, фрункцї, значення. Міжнародний науковий журнал "Інтернаука". 2018. № 7(1). С. 22-26.

20. Філоненко Б. Робити комікси з національними героями зараз на часі - Читомо URL: http://www.chytomo.com/ book-art/boris-filonenko-robiti-komiksi-z-nacionalnimi-geroyami-zaraz-na-chasi (дата звернення: 13.05.2019).

21. Харитошкин B.B. Комиксы в Европе - История комиксов. URL: http://comixy.narod.ru/evrocom.htm (дата звернення: 20.05.2021).

22. Эко У. Отсутствующая структура. Введение в селиологию. Санкт-Петербург : Петрополис, 1998.432 с.

23. Як і для чого використовувати візуалізацію даних? Ейдос. URL: http://eidos.org.ua/novyny/yak-i-dlya-chohovykorystovuvaty-vizualizatsiyu-danyh/ (дата звернення: 20.05.2021).

24. Lacassin F. Pour un neuvième art, la bande dessinée. Paris : Slatkine, 1982. 510 p. 
25. Onion D. The political influence in Americe during WWII - ThoughtHub. URL: https://www.sagu.edu/thoughthub/ the-political-influence-of-comics-in-america-during-wwii (дата звернення: 20.05.2021).

26. Thompson J. Manga: The Complete Guide. New York : Del Rey, (First Edition), 2007. 592 p.

\section{References:}

1. Abramchuk O.V. (2016) Zhanry suchasnoyi ukrayins `koyi literatury [Genres of modern Ukrainian literature]. Proceedings of the XLV Scientific and technical conference of Vinnytsia National Technical University (Ukraine, Vinnytsia, March 23-24, 2016), pp. 1-6. Available at: http://conferences.vntu.edu.ua/index.php/all-hum/allhum-2016/paper/view/108 (accessed 20 May 2021).

2. Belov D. (2018) Komiks yak produkt informacijnoyi kul tury [Comics as a product of information culture]. Naukovi Praci Nacional noyi Biblioteky Ukrayiny im. V.I. Vernads`kogo: zbirnyk Naukovi Praci [Scientific Papers of the National Library of Ukraine named after V.I. Vernadsky: a collection of scientific works] (electronic journal), vol. 49, pp. 71-88. Available at: http://nbuviap.gov.ua/images/naukprazi/49.pdf (accessed 20 May 2021).

3. Volkov A., Kutuzov V. (2017) Tajnaja istorija komiksov [The secret history of comics]. Moscow: AST. (in Russian)

4. V. Bugajov, D. Fadyeyev, O. Bondarenko, O. Fylypovych (2017) Volia [The Will]. Dnipro; Asgardian Comics. (in Ukrainian)

5. Gotra O. (2015) Istorychna pamyat yak chynnyk formuvannya identychnosti [Historical memory as a factor in the formation of identity]. INTERMARUM: istoriya, polityka, kultura [INTERMARUM: history, politics, culture] (electronic journal), vol. 2, pp. 143-155.

6. Zaharova I.V. (2017) Komiksy (La bande dessinée) vo franko-belgijskoj culture [Comics (La bande dessinée) in Franco-Belgian culture]. Moskovskij gosudarstvennyj universitet imeni M.V. Lomonosova [Moscow State University named after M.V. Lomonosov]. Available at: http://vernsky.ru/pubs/6836/Komiksy_La_bande_ dessin_e_vo_franko-belgiyskoy_kulture (accessed 20 May 2021).

7. Kosmatska N.V. (2012) Mova suchasnogo komiksu yak yavyshha masovoyi kultury [The language of modern comics as a phenomenon of mass culture]. Mova i kultura [Language and culture] (electronic journal), vol. 4, no. 15, pp. 15-20. Available at: http://nbuv.gov.ua/UJRN/Mik_2012_15_4_5 (accessed 20 May 2021).

8. Logvyn Yu. (1991) Pokhid Kniazia Oleha Na Tsarhorod [Prince Oleg's march on Constantinople]. Kyiv: Editorial office of children`s magazine "Sunflower". (in Ukrainian)

9. Maievskyi O. (2018) Formuvannia vizualnykh obraziv naperedodni ta u roky Pershoi svitovoi viiny [Formation of visual images on the eve and during the First World War]. Kraieznavstvo, vol. 14, p. 14.

10. Martynovych Yu. (2019) Komiks - Tse Maizhe film: Yak v Ukraini vidnovliuiut zabutyi deviatyi vyd mystetstva [Comics is almost a film: How the forgotten ninth art form is being restored in Ukraine]. ZIK [ZIK]. Available at: https://zik.ua/news/2019/01/07/komiks_tse_mayzhe_film_yak_v_ukraini_vidnovlyuyut_zabutyy_devyatyy_ vyd_1481711 (accessed 13 May 2019).

11. Mishenov Ya. (2018) Komiksy v Ukraini: rezultaty 2018 roku [Comics in Ukraine: the results of 2018]. Vertigo [Vertigo]. Available at: https://vertigo.com.ua/comics-in-ukraine-2018/ (accessed 20 May 2021).

12. Nahorna L. (2012) Istorychna pamiat teorii dyskursy refleksii [Historical Memory: Theories, Discourses, Reflections]. Kyiv: I. Kuras Institute for Political and Ethnonational Studies of the National Academy of Sciences of Ukraine. (in Ukrainian)

13. Nazarova Ye. (2017) «Ukrmen» ta inshi superheroi. yak rozvyvaietsia ukrainska industriia komiksiv ["Ukrmen" and other superheroes. How the Ukrainian comics industry is developing]. Radio Svoboda [Radio Svoboda]. Available at: https://www.radiosvoboda.org/a/yak-rozvyvayetsya-ukrayinska-industriya-komiksiv/29641200.html (accessed 20 May 2021).

14. Onkovich A. (2017) Komiksy kak forma vizual'noj mediakomunikacii [Comics as a form of visual media communication]. Institut vysshego obrazovanija Nacional'noj akademii pedagogicheskih nauk Ukrainy [Institute of Higher Education of the National Academy of Pedagogical Sciences of Ukraine]. Available at: https://dspace.kpfu.ru/xmlui/bitstream/handle/net/30146/viscom2014-85-92.pdf (accessed 20 May 2021).

15. Pozniak S. (1992) Bii Bohatyriv [Battle of the heroes]. Lviv: Khortytsia. (in Ukrainian)

16. Pozniak S. Derhachov O. Kovalenko O. (1993) Komiks-Zbirka № 1 [Comic book collection № 1]. Lviv: Phoenix Ltd. (in Ukrainian)

17. Pozniak S. (1992) Obloha Kyieva pechenihamy [Siege of Kiev by the Pechenegs]. Kyiv: Ukraina. (in Ukrainian)

18. Rynk O. (2017) Taiemna istoriia ukrainskykh komiksiv [The Secret History of Ukrainian Comics]. Vertigo [Vertigo]. Available at: https://vertigo.com.ua/history-of-ukrainian-comics/ (accessed 20 May 2021).

19. Troian T. H. (2018) Formuvannia komiks-kultury: perevahy, funktsii, znachennia [Formation of comic culture: advantages, functions, meanings]. Mizhnarodnyi Naukovyi Zhurnal «Internauka», vol. 7, no. 1, pp. 22-26.

20. Filonenko B. Robyty komiksy z natsionalnymy heroiamy zaraz na chasi [It's time to make comics with national heroes]. Chytomo [Chytomo]. Available at: http://www.chytomo.com/book-art/boris-filonenko-robiti-komiksi-znacionalnimi-geroyami-zaraz-na-chasi (accessed 13 May 2019).

21. Haritoshkin V. (2003) Komiksy v Evrope [Comics in Europe]. Istorija komiksov [History of comics]. Available at: http://comixy.narod.ru/evrocom.htm (accessed 20 May 2021).

22. Jeko U. (1998) Otsutstvujushhaja struktura. Vvedenie v semiologiju [Missing structure. Introduction to semiology]. Saint Petersburg: Petropolis. (in Russian)

23. Tarnai V. Yak i dlia choho vykorystovuvaty vizualizatsiiu danykh? [How and for whom is it to be victorious in the visualization of the tribute?]. Eidos [Eidos]. Available at: http://eidos.org.ua/novyny/yak-i-dlya-chohovykorystovuvaty-vizualizatsiyu-danyh/ (accessed 20 May 2021).

24. Lacassin F. (1982) Pour un neuvième art, la bande dessinée. Paris: Slatkine, 510 p.

25. Onion D. The political influence in Americe during WWII. ThoughtHub. Available at: https://www.sagu.edu/ thoughthub/the-political-influence-of-comics-in-america-during-wwii (accessed 20 May 2021).

26. Thompson J. (2007) Manga: The Complete Guide. New York: Del Rey, (First Edition), 592 p. 